\title{
Necessary conditions and methodology for fitting pore size distribution curves
}

\begin{abstract}
The analysis was conducted for both MICP and adsorption cumulative pore distribution curves. The big question was: is it possible to fit both curves to obtain one pore size distribution curve, covering the whole range of interesting pore radii. Analysis of conducted research showed that curves could only be identical in certain ranges of pore radii. In other words, their relationship is defined, by the flow phenomena in nanopores which depends on pore diameter and shape. Merging of both curves gives additional information about the pore structure of investigated rocks.
\end{abstract}

Key words: Flow of fluids, nanopore space, pore radius distribution curves.

\section{Warunki konieczne i metodologia dopasowywania krzywych rozkładu wielkości porów}

Przeanalizowano krzywe kumulacyjne otrzymane z pomiarow porozymetrii ręciowej oraz z badań adsorpcyjnych. Podstawowym problemem była możliwość połączenia obu krzywych w jedną, obejmującą cały zakres interesujących porów. Stwierdzono, że jedynie dla pewnych interwałów obie krzywe mogą mieć identyczny przebieg. Dla innych zakresów, szczególnie dla nanoporów, ich przebieg jest inny i jest sterowny przez inne zjawiska zachodzące przy przepływie płynów przez nanoprzestrzeń porową. Tym niemniej takie próby łączenia obu krzywych dają dodatkową informację o badanych skałach.

Słowa kluczowe: przepływ płynów, przestrzeń nanoporowa, krzywe rozkładu promieni porów.

Analysis of a fluid flow through shale rock pore space, depends on finding the real value of permeability, as well as estimating the total flux of flowing fluid. One of the most useful and necessary tools in such analysis is pore radius or pore diameter distribution curve. It allows us to apply - for example - net model of pore space $[2,12]$. Generally two types of analyses give such a data. The first, is the high pressure MICP in which distribution of pore throats curve, is obtained directly from capillary pressure curve and Washburne's formula [22]. The second is the adsorption investigation. For a geological sample, the pore distributions are calculated mainly from Halsey equation $[6,17]$. Both methods are based on the capillary tube model. The first one covers the range of pores from several hundred micrometers to 5 nanometers, the second one from 300 to 2 nanometers.

A combination of MICP and $\mathrm{N}_{2}$ adsorption provides complementary information about entire pore structure. However, a direct comparison of the pore volumes from those two techniques might be tricky because of difference in basic principles. The intrusion of mercury is controlled by the pore throats, while the nitrogen adsorption phenomenon is controlled by the pore body.

Moreover, special attention should to be paid to MICP data analysis of shale rocks. In such samples, the course of the cumulative curves may reflect the changes in sample caused by application of high pressure (up to $414 \mathrm{MPa}$ ), which may significantly affect the data by compressing the rocks structure, breaking the particles and opening closed pores $[4,6,9,12,13]$.

Those two measurement techniques record different aspects of the pore structure. So then the questions which arises are: is there any systematic compliance between parameters provided by different methods and is it possible to gather the results into one reliable curve? 


\section{Results and Discussion}

A typical cumulative curve of pore size distribution is presented in Fig. 1. It gives pore volume as a function of pore throats. The marked area above the second inflexion point shows the range of pore diameters (radii) in which manifests itself the fractal structure of pore throats (channels). Fractal dimension is equal to

$$
D=3-A
$$

where $A$ is the direction coefficient of straight line obtained from $\log$ (mercury saturation) - $\log$ (pore diameter) plot [22]

The mercury injection capillary pressure cumulative curve in fact, shows the process of saturation of pore space as a function of pore channel (throat) diameters $[7,11]$.

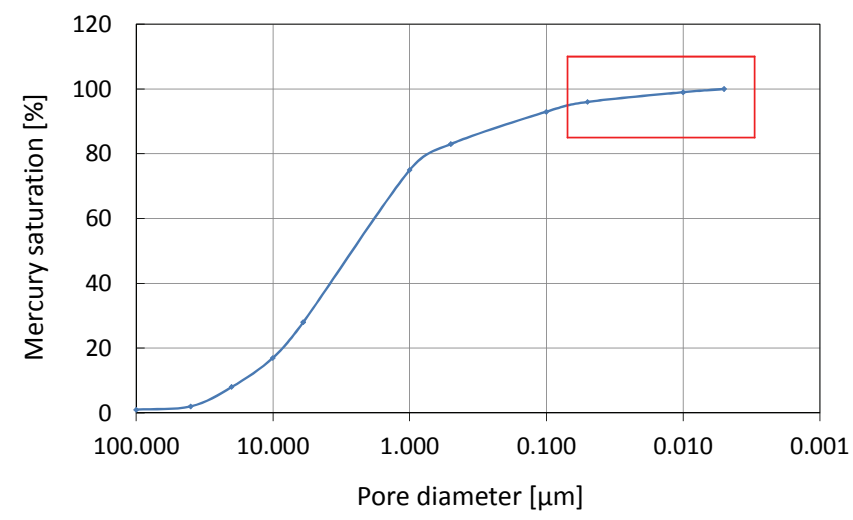

Fig. 1. Typical MICP curve (marked pore diameter range of evident pore channels fractal structure)

For the same collection of samples, $\mathrm{N}_{2}$ adsorption experiments were performed $[7,16]$. Cumulative curves of pore size distribution were obtained using BJH theory and Halsey equation for pores, throats and channels cover the range $170 \div 2 \mathrm{~nm}[3,10,23]$.

In that range additional fractal structures might be determined, which reflect monolayer and multilayer adsorption, and can provide additional information about surface area and capillary condensation, respectively [5] (Fig. 3).

The cumulative curve obtained based on adsorption isotherm (Fig. 2) is presented in Fig. 3. The course of the cumulative curve is not only dependent on pore volume as a function of pore bodies, because of various flow mechanism which changes with the pore size $[8,12,18]$.

Above $100 \mathrm{~nm}$ radius dominates Darcy flow, so flow is well described using the net model of pore space [12, $20,23]$. That means extraction of pore throats diameter distribution as well as fractal dimension. The MICP analyses are best for such conditions and could give us all the necessary data.

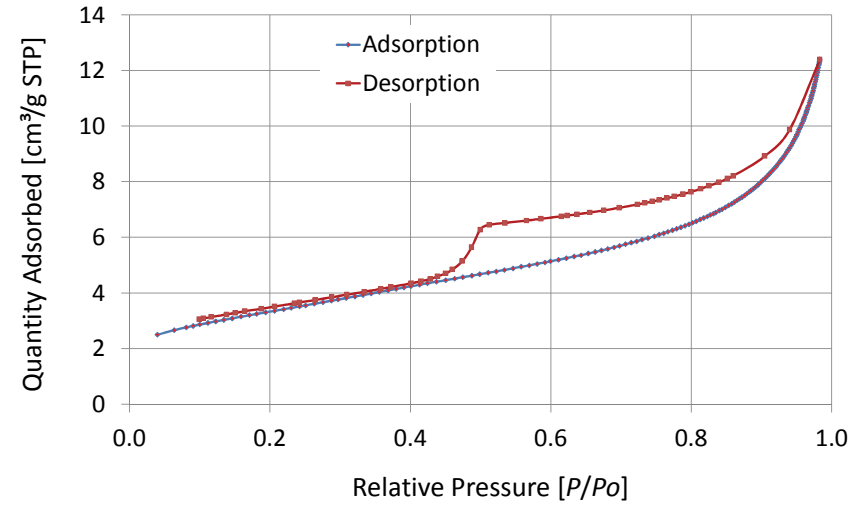

Fig. 2. Typical $\mathrm{N}_{2}$ adsorption curve

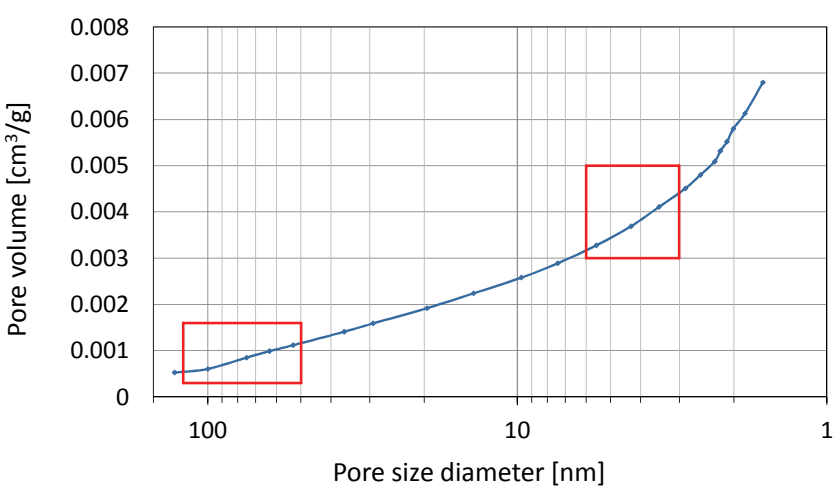

Fig. 3. Cumulative pore size distribution as obtained from adsorption experiment (marked pore diameter range which reflect fractal structure)

In the range $10 \div 100 \mathrm{~nm}$ situation changes. Darcy flow regime changes into slip flow regime and $K_{A p p}$ increases $[8,12$, $13,15]$. Additionally another factor starts to dominate in the flow phenomena: both Knudsen diffusion and self difussion. As a result $K_{A p p}$ becomes greater than Darcy permeability. This dependence is illustrated in Fig. 4 [20].

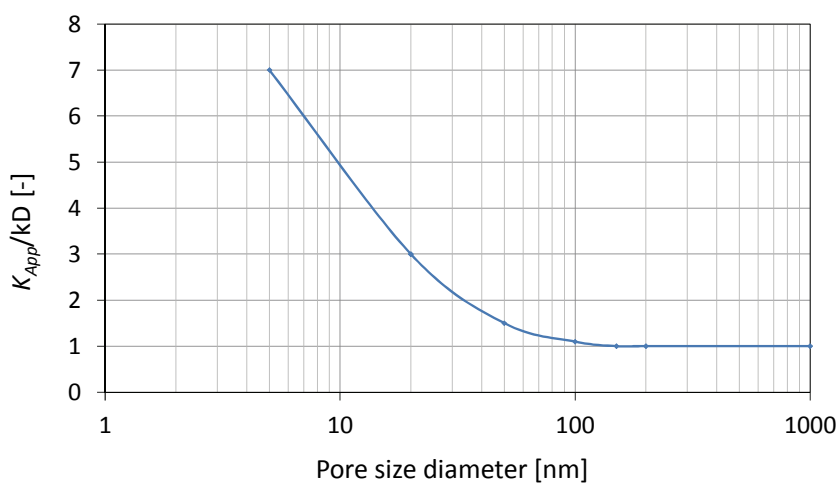

Fig. 4. $K_{A p p} / k$ (Darcy) in a function of pore diameter [19]

In the range of radii covered within $100 \div 10 \mathrm{~nm}$, it is necessary to take into consideration the following: 
- rocks compressibility - this process occurs during high pressure MICP measurements. Compressibility shift this curve towards lower values of pore radiuses and decrease dynamic porosity. The influence of compressibility on obtained results, depends on type of shale rock, its mineral composition and rigidity [21].

- slip flow - it depends on the same factor in both methods (pore throat). It means that both curves ought to be similar up to the critical value of pore radii, at which molecular diffusion and self diffusion occurs.

- molecular diffusion - this process depends on pore throats and pore bodies [24]. Slip flow still exists. Therefore this combined flow is more efficient than a single one (Fig. 4). Below the critical value of pore radius, the ad- sorption curve should lie higher than the mercury curve (because it depends on pore bodies). The critical radius value depends on the shape of pores and the mineralogical composition.

Summarizing, it may be stated that for pore radii greater than the critical value, the MICP curve is valid. Below the critical radius, the adsorption curve ought to be used for pore space description. There are some problems with the great space heterogenity of pore space parameters $[3,7,19]$, so practically the only solution is to use the same sample of shale rock for both analyses.

Moreover, additional factors like mixed wettability and destruction of pore space by mercury could also affect final results $[1,8]$.

\section{Combining MICP and $\mathrm{N}_{2}$ adsorption data}

29 randomly choosen shale samples were used in this investigation. Their frequency diagram of total porosity is presented in Fig. 5.

The first twenty MICP and adsorption curves were obtained using rocks from the same core, but two seperate samples of each, previously homogenized using quarter technique, were prepared for the analyses. The tests of the last nine rocks were done strictly on the same samples. The adsorption measurement was performed as the first one and then the same sample was used in MICP experiment. These sample showed similar average porosity as the other samples from the database.

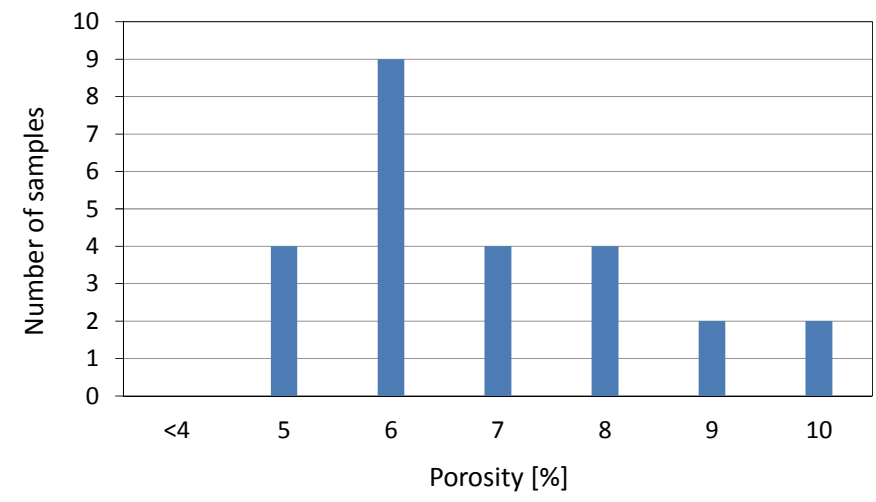

Fig. 5. Frequency diagram of total porosity for investigated samples

All investigated samples can be divided into three groups:

- The first group includes 21 samples, satisfying theoretical considerations and the results allow to merge both curves. Values of the critical radius for a greater part of the samples from this group cover the range $10 \div 45 \mathrm{~nm}$ (Fig. 7A). The frequency diagram of the critical radius is presented in Fig. 6. For three samples, critical radius is equal to $10 \mathrm{~nm}$ (Fig. 7B). This effect shows that pore space in these rock is in fact similar to the bundle of capillary tubes (pore throats are equal to pore bodies).

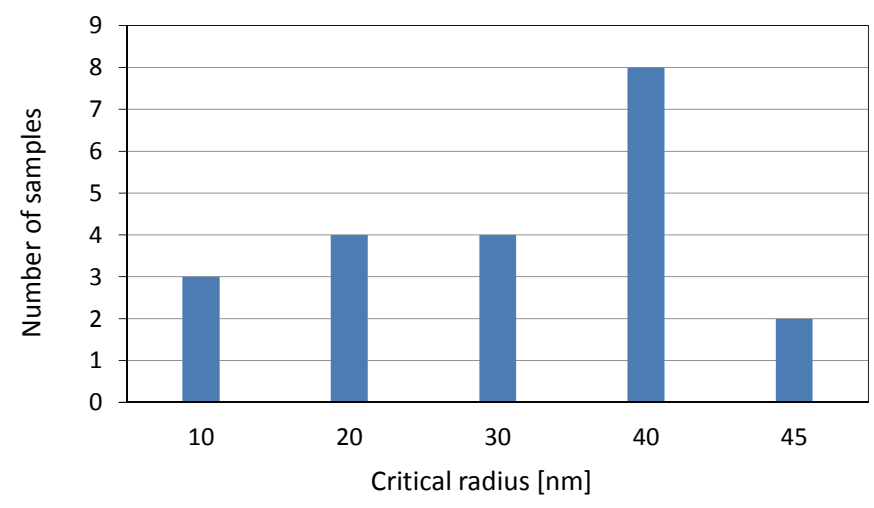

Fig. 6. Frequency diagram of obtained ciritical radiuses

- 4 samples can be assigned to the low porosity second group of samples in which great discrepancies between both curves are observed. Probably taking into account low porosity, volumes of rocks used in the experiment are too small. This restriction is caused by apparatus construction or by greater relative space heterogenuity caused by low porosity (Fig. 7C).

- Another 4 samples belong probably to very heterogenius rocks. MICP and cumulative curves obtained from adsorption experiments look like curves from completely different samples (Fig. 7D). 


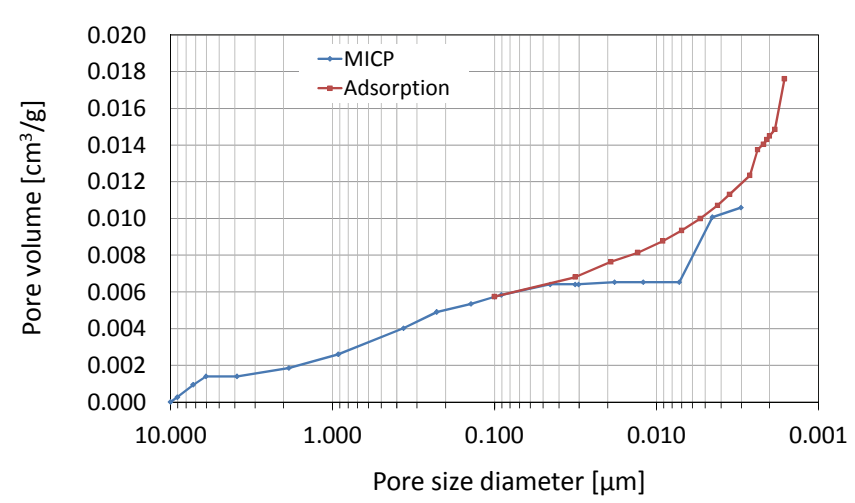

Fig. 7A. Good merged curves. Critical radius is equal to $40 \mathrm{~nm}$

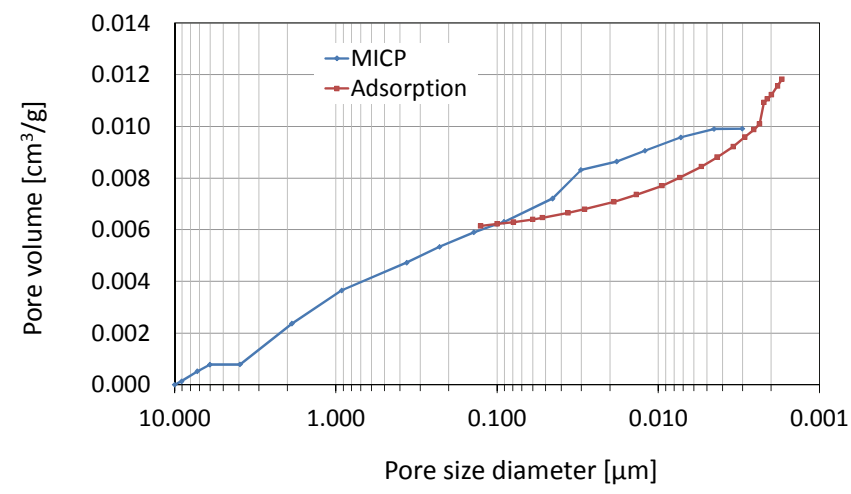

Fig. 7C. MICP and adsorption curves for low porous rock

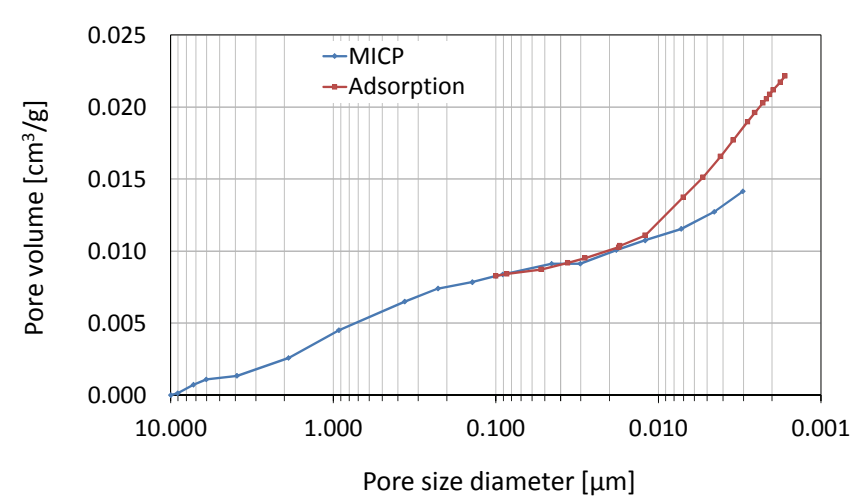

Fig. 7B. Merged curves for the critical radius equal to $10 \mathrm{~nm}$

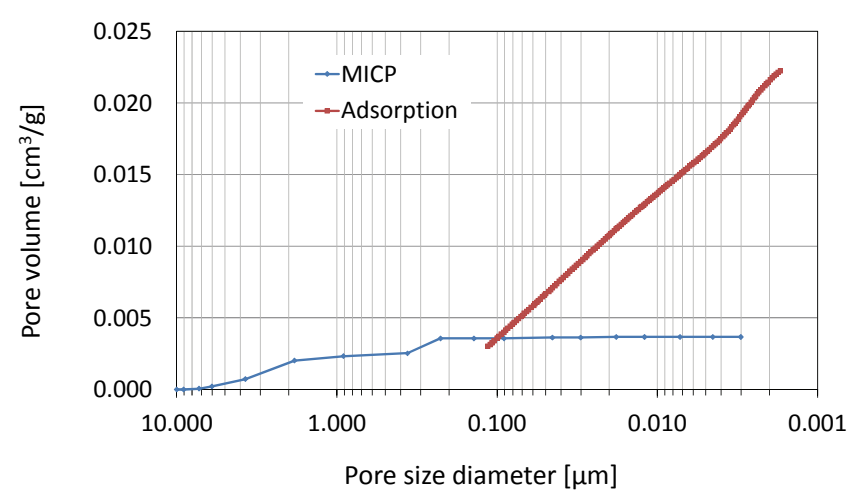

Fig. 7D. MICP and adsorption curves for heterogenous rock

\section{Inaccessible porosity}

This problem was considered by several authors $[6,7$, 13, 14]. Inaccessible means porosity not penetrated even by helium, during total porosity measurements with the use of a powdered sample. $5 \div 15 \%$ of investigated samples from Polish shale gas reservoirs, showed during MICP experiments the effect shown in Fig. 8. In the range of pore radiuses $10 \div 1 \mathrm{~nm}$ obtained mercury (dynamic) porosity is greater than total porosity calculated from helium pycnometry.

The observed effect must be connected with the collapse of closed nanopores, which existed in investigated rocks under very high mercury pressure, during MICP investigations (414 MPa). They were isolated nanopores but their number gives a cumulative effect equal to $30 \%$ of total porosity. This is a problem for an independent investigation. Now this problem is only noted.

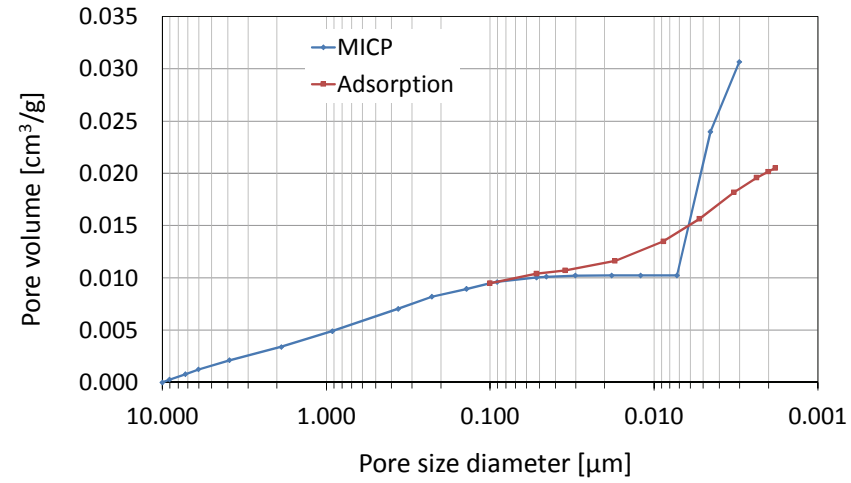

Fig. 8. Effect of the collapse of closed nanopores under high pressure of mercury (dynamic porosity calculated from MICP analysis is greater than total porosity)

\section{Conclusion}

Conclusions can be summarized as follows:

- merging two pore radius cumulative curves gives additional information about the investigated rocks (inaccessible porosity, rigidity) and the quality of measurements,

- merged curves verify both quality of investigations and calculation procedures (adsorption model and theory),
- value of critical radius gives information about pore shapes, pores morphology and effects which may occur in the pore space (capillary condensation),

- shape of merged curve is a good indicator in choosing an appropriate model of permeability and total flux calculations. Effect of collapse is presented in 5.15\% samples. 
Please cite as: Nafta-Gaz 2016, no. 9, pp. 691-695, DOI: 10.18668/NG.2016.09.02

Article contributed to the Editor 8.03.2016. Approved for publication 24.05.2016.

\section{Literature}

[1] Adesida A. G., Akkutlu I. Y., Resasco D. E., Rai C. S.: Kerogen pore size distribution of Barnett Shale using DFT analysis and monte carle simulation. SPE Paper 147397, 2011.

[2] Anovitz L. M., Cole D. R.: Characterization and Analysis of Porosity and Pore Structures. Reviews in Mineralogy \& Geochemistry 2015,vol. 80, pp. 61-164.

[3] Barrett E. P., Joyner L. S., Halenda P. P.: The determination of Pore Volume and Area Disrtibutions in Porous Substances. I. Computations from Nitrogen Isoterms. Journal of American Chemical Society 1951, vol. 73, no. 5, pp. 373-380.

[4] Bustin R. M., Bustin A. M., Cui X., Ross D., Murthy J. K., Pathi V. S.: Impact of Shale properties on pore structure and storage characteristics. SPE 119892-MS, presented at the SPE Shale Gas Production Conference, Forth Worth, Texas, USA, 16-18 November 2008.

[5] Cicha-Szot R., Dudek L., Such P.: Charakterystyka fraktalna przestrzeni porowej skat tupkowych. Przemyst Chemiczny 2015, vol. 94, no. 12, pp. 2279-2287.

[6] Clarkson C. R., Freeman M., He L., Agamalian M., Melnichenko Y. B., Mastalerz M., Bustin R. M., Radlinski A. P., Blac T. P.: Characterization of tight gas reservoir pore structure using USANS/SANS and gas adsorption analysis. Fuel 2012, vol. 95, pp. 371-385.

[7] Clarkson C. R., Solano N., Bustin R. M., Chalmers G. R. L., He L., Melnichenko Y. B., Radlinski A. P., Blach T. P.: Pore structure characterization of North American shale gas reservoirs using USANS/SANS, gas adsorption, and mercury intrusion. Fuel 2013, vol. 103, pp. 606-616.

[8] Clarkson C. R., Wood J., Burgis S., Aquino S., Freeman M.: Nanopore-Structure Analysis and Permeability Predictions for a Right Gas Siltstone Reservoir by Use of Low-Pressure Adsorption and Mercury Instrusion techniques. SPE Paper 155537, 2012.

[9] Comisky J., Santiago M., McCollom B., Buddhala A., Newsham K.: Sample size effects on the application of mercury injection capillary pressure for determining the storage capacity of tight gas and oil shales. SPE 149432-MS, Presented at the Canadian Unconventional Resources Conference, Alberta, Canada 15-17 November 2011.

[10] Halsey G.: Physical Adsorption on Non-uniform Surfaces. The Journal of Chemical Physics 1948, vol. 16, pp. 931-937.

[11] Howard J. J.: Porosimetry measurementm of shale fabric and its relationship to illite/smectite diagenesis. Clays and Clay Minerals 1991, vol. 39, no. 4, pp. 355-361.

[12] Javadpour F.: Nanopores and Apparent Permeability of Gas Flow in Mudrocks (Shales and Siltstones). Journal of Canadian Petroleum Technology 2009, vol. 48, pp. 16-21.

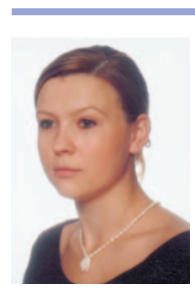

Renata CICHA-SZOT M.Sc. Eng.

Junior Scientist

Department of Petroleum Engineering

Oil and Gas Institute - National Research Institute

ul. Lubicz 25 A

31-503 Kraków

E-mail: renta.cicha@inig.pl
[13] Kuila U., Prasad M.: Specific Surface area and pore-size distribution in clays and shales. Geophysics Prospecting 2013, vol. 61, pp. 341-362.

[14] Kuilla U., Prasad M.: Surface area and pore-size distribution in clays and shales. SPE Paper 146869, 2011.

[15] Mao Sheng: Shale gas permeability model with effects of multiscale flow based on fractal pore space geometry. Fractals 2015 - manuscript number D-14-00092.

[16] Mroczkowska-Szerszeń M.: The analysis of pore space parameters of shale gas formations rocks within the range of 50 to $2 \mathrm{~nm}$. Nafta-Gaz 2015, no. 12, pp. 983-991.

[17] Neimark A. V., Ravikovitch P. I.: Calibration of Pore Volume in Adsorption Experiments and Theoretical Models. Langmuir 1997, vol. 13, pp. 5148-5160.

[18] Ross D. J. K., Bustin R. M.: Impact of mass balance calculations on adsorption capacities in microporous shale gas reservoirs. Fuel 2007, vol. 86, pp. 2696-2706.

[19] Ross D. J. K., Bustin R. M.: The importance of shale composition and pore structure upon gas storage potential of shale gas reservoirs. Marine and Petroleum Geology 2009, vol. 26, pp. 916-927.

[20] Such P.: Przeplyw gazu przez nanopory - próba oceny. Nafta-Gaz 2014, no. 10, pp. 671-675.

[21] Such P., Dudek L., Mroczkowska-Szerszeń M., Cicha-Szot R.: The influence of reservoir conditions on filtration parameters of shale rocks. Nafta-Gaz 2015, no. 11, pp. 827-833.

[22] Such P., Leśniak G., Budak P.: Kompleksowa metodyka badania właściwości petrofizycznych skat. Prace Instytutu Nafty i Gazu 2007, no. 142, pp. 1-69.

[23] Wang R., Zhang N., Liu X., Wu X., Yan J.: Characterization of Gas Flow Ability and Contribution of Diffusion to Total mass Flux in the Shale. Research Journal of Applied Sciences, Engineering and Technology 2013, vol. 6, no. 9, pp. 1663-1668.

[24] Wang S., Javadpour F., Feng O.: Confinement Correction to mercury Intrusion Capillary Pressure of Shale Nanopores. Scientific Reports 2016, no. 6. Article number: 20160.

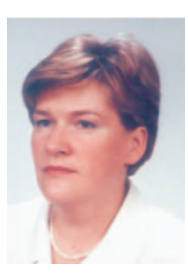

Lidia DUDEK M.Sc. Eng.

Senior Technical Research Specialist

Department of Geology and Geochemistry

Oil and Gas Institute - National Research Institute

ul. Lubicz 25 A

31-503 Kraków

E-mail:dudekl@inig.pl

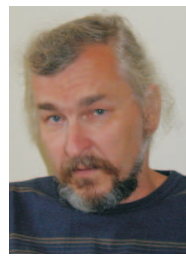

Prof. dr hab. Piotr Such

Assoc. Professor

Deputy Director

Exploration of Hydrocarbons

Oil and Gas Institute - National Research Institute

ul. Lubicz 25 A, 31-503 Kraków

E-mail: piotr.such@inig.pl 